Review

\title{
Acute and Preventive Management of Migraine during Menstruation and Menopause
}

\author{
Raffaele Ornello (D), Eleonora De Matteis, Chiara Di Felice (D), Valeria Caponnetto, Francesca Pistoia \\ and Simona Sacco *iD
}

check for updates

Citation: Ornello, R.; De Matteis, E.; Di Felice, C.; Caponnetto, V.; Pistoia, F.; Sacco, S. Acute and Preventive Management of Migraine during Menstruation and Menopause. J. Clin. Med. 2021, 10, 2263. https://doi.org/ $10.3390 / \mathrm{jcm} 10112263$

Academic Editor: Antonio Russo

Received: 29 April 2021

Accepted: 19 May 2021

Published: 24 May 2021

Publisher's Note: MDPI stays neutral with regard to jurisdictional claims in published maps and institutional affiliations.

Copyright: (c) 2021 by the authors. Licensee MDPI, Basel, Switzerland. This article is an open access article distributed under the terms and conditions of the Creative Commons Attribution (CC BY) license (https:// creativecommons.org/licenses/by/ $4.0 /)$.
Neuroscience Section, Department of Applied Clinical Sciences and Biotechnology, University of L'Aquila, 67100 L'Aquila, Italy; raffaele.ornello@univaq.it (R.O.); eleonoradematteis@fastwebnet.it (E.D.M.); chiaradi.felice@yahoo.com (C.D.F.); valeria.caponnetto@univaq.it (V.C.); francesca.pistoia@univaq.it (F.P.)

* Correspondence: simona.sacco@univaq.it; Tel.: +39-0862433561

\begin{abstract}
Migraine course is influenced by female reproductive milestones, including menstruation and perimenopause; menstrual migraine (MM) represents a distinct clinical entity. Increased susceptibility to migraine during menstruation and in perimenopause is probably due to fluctuations in estrogen levels. The present review provides suggestions for the treatment of MM and perimenopausal migraine. MM is characterized by long, severe, and poorly treatable headaches, for which the use of long-acting triptans and/or combined treatment with triptans and common analgesics is advisable. Short-term prophylaxis with triptans and/or estrogen treatment is another viable option in women with regular menstrual cycles or treated with combined hormonal contraceptives; conventional prevention may also be considered depending on the attack-related disability and the presence of attacks unrelated to menstruation. In women with perimenopausal migraine, hormonal treatments should aim at avoiding estrogen fluctuations. Future research on migraine treatments will benefit from the ascertainment of the interplay between female sex hormones and the mechanisms of migraine pathogenesis, including the calcitonin gene-related peptide pathway.
\end{abstract}

Keywords: migraine; menstruation; menopause; migraine treatment; triptans; hormonal treatments

\section{Introduction}

Migraine is a common headache disorder affecting $14 \%$ of people worldwide [1]. Migraine commonly affects young people and especially women; indeed, the prevalence of migraine is three to four times higher in women compared with men [1-3]. Different mechanisms might explain the female predominance of migraine, including the migraineenhancing role of female sex hormones and a higher genetic heritability in women compared with men [4]. Of note, migraine prevalence is the same in women and in men during childhood, while a higher prevalence of migraine in women than in men is found only after puberty, when women start menstruating [5]. According to the so-called "estrogen withdrawal hypothesis", the cycles of rise and fall in estrogen levels typical of the female fertile period are deemed responsible for an increased susceptibility to migraine in women [6]. Estrogen levels undergo a sudden fall during the days immediately preceding menstruation $[7,8]$. Hence, the highest susceptibility to migraine is in the perimenstrual period. The years immediately preceding and following the menopause also pose women at an increased risk of having severe migraine [9] due to the rapid fluctuations in estrogen levels that accompany this phase of the female reproductive cycle.

Estrogen withdrawal can partly explain the effect of female sex hormones on migraine; however, the influence of sex hormones on migraine mechanisms is complex and not fully elucidated. Sex hormones influence nociceptive processing, acting on both central and peripheral pathways [10]. Animal studies have found a broad localization of estrogen receptors in brain structures involved in migraine generation, including the trigeminal ganglion [11] and pain-processing structures within the brain [12]. At a central level, 
estrogens can activate the endogenous opioid system that controls pain sensations [13] and modulate the levels of oxytocin, a neurohormone released by the hypothalamus, which can exert an anti-migraine effect [14]. Notably, both estrogens [15] and oxytocin [16] might act on the trigeminal ganglion and modulate the release of calcitonin gene-related peptide (CGRP), which is implied in the generation of migraine pain. Progestins might also attenuate pain responses via conversion to the neurosteroid allopregnanolone, as suggested by animal evidence [17]. Taken all together, female sex hormones influence the susceptibility to migraine, acting through a complex interplay of central and peripheral pathways (Figure 1).
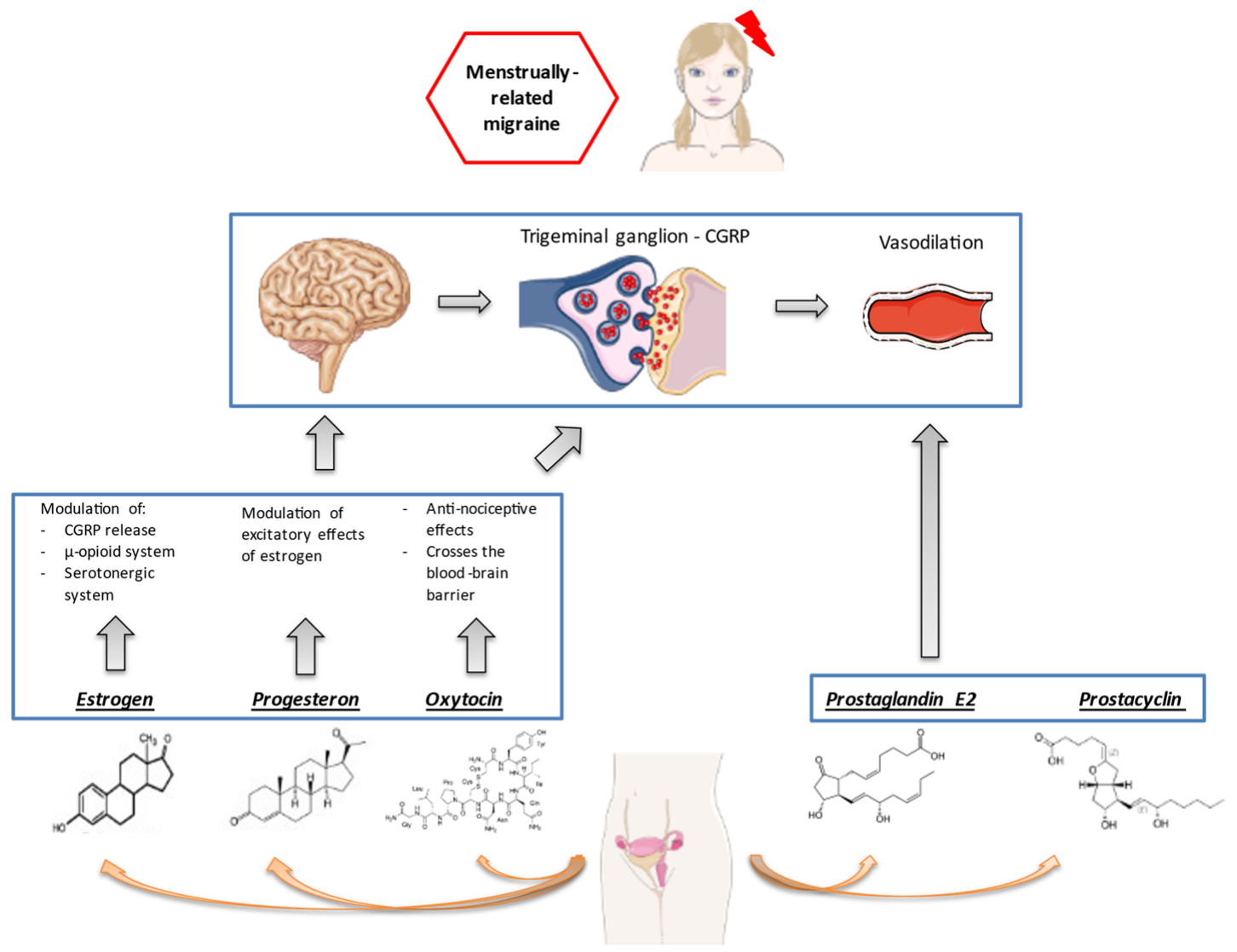

Figure 1. Female sex hormones and pathogenesis of menstrual migraine.

The influence of female hormonal fluctuations on migraine is so remarkable that menstrual migraine (MM) is recognized by the current international classification as a distinct headache disorder [18]. In detail, pure menstrual migraine occurs exclusively on day $1 \pm 2$ of menstruation in at least two out of three menstrual cycles and at no other times of the cycle, while menstrual-related migraine occurs on day $1 \pm 2$ of menstruation in at least two out of three menstrual cycles, and additionally at other times of the cycle [18] (Figure 2). Differently from MM, perimenopausal migraine is not recognized as an independent clinical entity.

The treatment of MM and perimenopausal migraine generally follows the indications for the acute and preventive treatment of any other form of migraine, in the absence of specific indications. Nevertheless, some additional considerations are needed when migraine occurrence is influenced by female sex hormones.

In the present paper, we narratively reviewed the current concepts on the treatment of menstrual and perimenopausal migraine and the possible lines of future treatments, with a focus on practical suggestions. 


\section{PURE MENSTRUAL MIGRAINE}

- Attacks, in a menstruating woman, fulfilling criteria for migraine

- occurring exclusively on day $1 \pm 2$ (ie,

days -2 to +3 ) of menstruation (or

hormene free interval of hormon

treatments) in at least two out of the

menstrual cycles and at no other times of

the cycle.

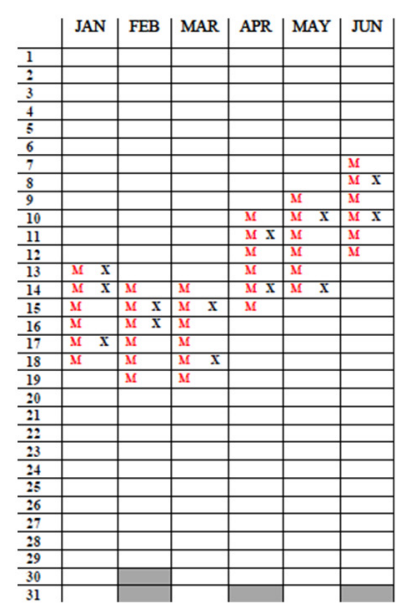

\section{MENSTRUALLY-RELATED MIGRAINE}

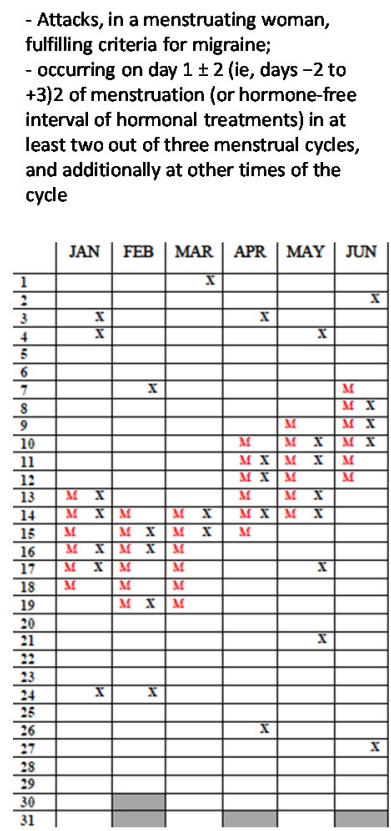

Figure 2. Example of headache diary of patient with pure menstrual and menstrual-related migraine. The Xs represent headache days; Ms represent reported menstruation days.

\section{Methods}

We searched PubMed and Scopus for articles containing the terms "migraine", "menstrual", "menopause", and "treatment", up to February 2021. We included reviews and original articles. Due to the broadness of the topic and the inclusion of the authors' personal views, we did not perform a systematic review.

\section{The Burden and Unmet Needs of Women with Menstrual and Perimenopausal Migraine}

MM affects 3\% of young women [19], with a peak of 22\% in women aged 30-34 years [20]. According to several studies, migraine attacks occurring during the perimenstrual period are longer, more severe, have more associated symptoms, and are less responsive to acute medication compared with non-menstrual migraine attacks [21-24]. Menstruation is a poorly controllable hormonal trigger which exposes women to anticipatory anxiety of headaches, so-called "cephalalgiaphobia" [25]; this fear of headache could lead, in turn, to increased consumption of painkillers [26].

The reported prevalence of migraine during the menopause is 10-29\% [9]. The years immediately preceding and following the menopause are characterized by an increased susceptibility to migraine $[27,28]$ due to the frequent rise and fall of estrogen levels before reaching stable low levels years after the menopause [9]. After natural menopause, migraine usually improves [28,29], while women undergoing surgical menopause have a high risk of migraine worsening, possibly due to a sudden fall in estrogen levels [30,31]. The proportion of women reporting postmenopausal migraine worsening is particularly high in headache clinics, possibly due to selection bias [9,32]. Therefore, headache clinics likely provide care to a high proportion of women with perimenopausal migraine worsening, and women with previously rare migraines can come to the attention of a headache center for the first time because of a perimenopausal worsening.

The high burden of hormonally triggered migraine in women can lead to decreased quality of life and high disability (Figure 3). However, specific strategies for the management of hormonal triggers need to be better defined. 


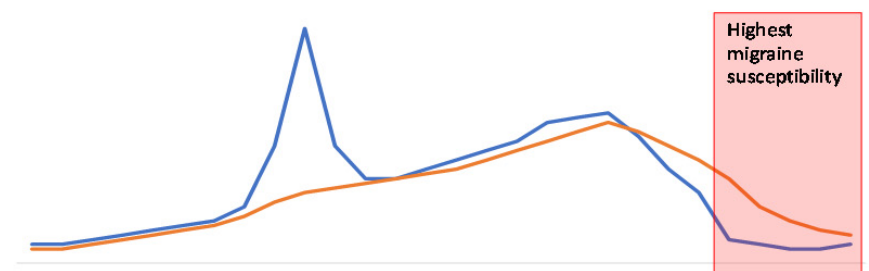

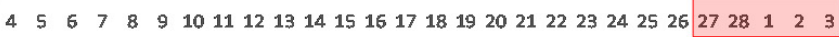
Days of menstrual cycle

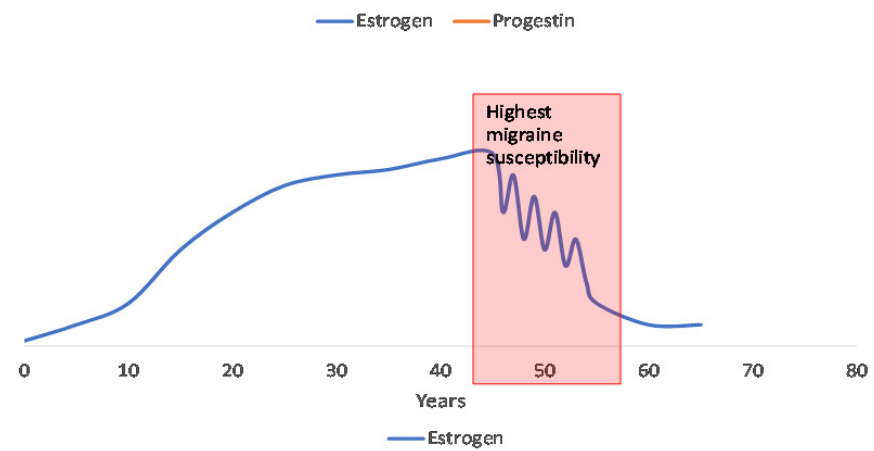

Significant impact on daily activities [19]
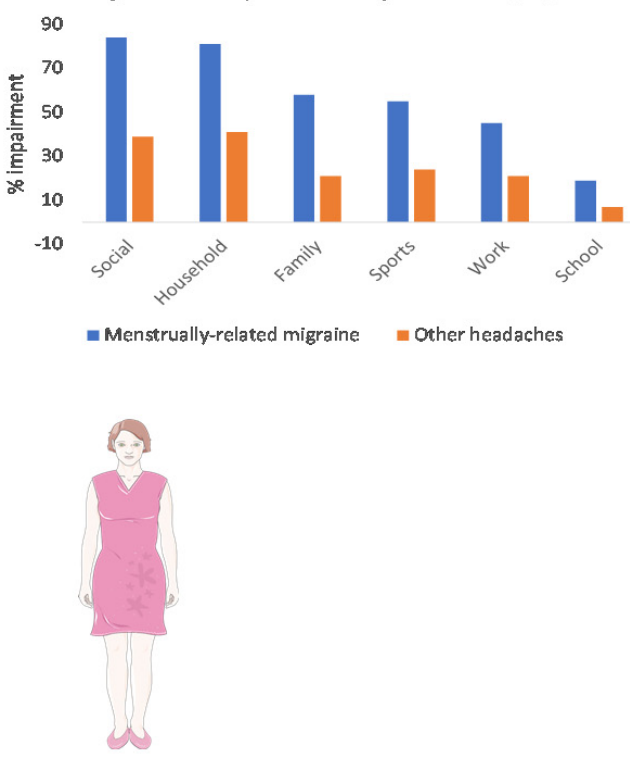

Figure 3. Graphical representation of the menstrual and perimenopausal periods of increased susceptibility to migraine and women's quality of life impairment. The panels on the left indicate the levels of female sex hormones during the menstrual cycle (above) and the years of women's life (below). The graph on the right shows the proportion of women reporting impairment of daily activities due to menstrual-related migraine (blue columns) compared with other headaches (orange columns; data from [19]).

\section{Acute Treatment of Menstrual Migraine}

\subsection{Triptans}

There is currently no acute treatment specifically designed for MM. The use of triptans for the treatment of MM has been extensively evaluated. Randomized controlled trials and open-label studies have established the efficacy of sumatriptan [33-35], frovatriptan [36], naratriptan [37], zolmitriptan [38], and almotriptan [39] for the acute treatment of MM (Table 1). All triptans were more effective than placebo in relieving pain during the first 2-4 h; however, most triptans were not superior over placebo in preventing migraine recurrence within $24 \mathrm{~h}$ from taking the drug [33,34]. Frovatriptan had better performances over the other triptans [40-42], possibly due to its longer half-life; hence, it could be advisable for use in MM, whose attacks are usually longer compared with those in the intermenstrual period [4].

\subsection{Common Analgesics}

Although being migraine-specific, triptans are not the only drugs that can be used for the acute treatment of MM. The use of simple analgesics in MM is justified by the increased release of prostaglandins during the perimenstrual period, which leads not only to perimenstrual pain, but also to an increased proneness to migraine. This hypothesis is supported by the increase in prostaglandin salivary levels which was found in women with migraine and associated dysmenorrhea [43]; further studies found an association between migraine and dysmenorrhea [44] and that the infusion of prostaglandins can induce migraine attacks in women with migraine with aura [45]. Mefenamic acid, an inhibitor of prostaglandin synthesis, effectively treated MM in an early trial [46]. The commonly used nonsteroidal anti-inflammatory drugs inhibit prostaglandin synthesis by inhibiting cyclooxygenase enzymes [47] and can therefore be used in the acute treatment of MM, especially in women with dysmenorrhea. Except from mefenamic acid, there are no studies of nonsteroidal anti-inflammatory agents specifically addressing their use in MM. 


\subsection{General Considerations on the Acute Treatment of $M M$}

It is important that drugs are taken soon after the beginning of pain, when it is still mild, to maximize their efficacy [35]. This treatment principle is far more important for menstrual episodes, which impose a high burden of pain on women compared with non-menstrual episodes. Not only the type of drugs, but also their mode of administration can influence their effectiveness in the acute management of MM; as MM is associated with an increased occurrence of gastrointestinal symptoms, such as nausea and vomiting, using non-oral formulations can contribute to increasing the effectiveness of acute treatments. This view is supported by a pilot trial which showed a higher performance of sumatriptan suppositories over sumatriptan tablets in relieving pain, associated symptoms, and pain recurrence [48].

As stated before, MM attacks tend to require a high use of acute treatment. Triptans and common analgesics act on different pathways; therefore, combining triptans with analgesics is an alternative approach to effectively treat MM. The available trials confirmed the efficacy of sumatriptan plus naproxen [49-52] and of frovatriptan plus dexketoprofen [53] (Table 1). Common analgesics can also be used as a rescue treatment if triptans fail. It is advisable that patients adopting rescue treatments take a triptan first to maximize its efficacy; common analgesics can be taken soon after the triptan, maintaining gastrointestinal safety.

Table 1. Summary of drugs for the acute treatment of menstrual migraine. OLS indicates open-label study; RCT, randomized controlled trial.

\begin{tabular}{|c|c|c|}
\hline Drug & Available Studies & Main Findings \\
\hline \multicolumn{3}{|l|}{ Single drug } \\
\hline Frovatriptan & $\begin{array}{l}5 \text { RCTs vs. other triptans } \\
\text { [40-42]; } 1 \text { OLS }\end{array}$ & $\begin{array}{c}\text { Early relief: superior to placebo, equivalent to other triptans } \\
\text { Sustained relief: superior to almotriptan, rizatriptan, zolmitriptan } \\
\text { Non-headache symptoms: effective on nausea and phonophobia, not } \\
\text { on other symptoms } \\
\text { Adverse events: comparable to placebo } \\
\text { Other outcomes: higher patient satisfaction with frovatriptan } \\
\text { compared with previous treatments }\end{array}$ \\
\hline Sumatriptan & 3 RCTs [33-35] & $\begin{array}{l}\text { Early relief: superior to placebo } \\
\text { Sustained relief: comparable to placebo } \\
\text { Non-headache symptoms: effective on photophobia and phonophobia } \\
\text { Adverse events: comparable to placebo }\end{array}$ \\
\hline Naratriptan & $1 \mathrm{RCT}[37]$ & $\begin{array}{c}\text { Early relief: superior to placebo } \\
\text { Sustained relief: superior to placebo } \\
\text { Non-headache symptoms: superior to placebo for all symptoms } \\
\text { Adverse events: comparable to placebo } \\
\text { Other outcomes: superior to placebo in ability to carry on daily } \\
\text { activities and patient satisfaction }\end{array}$ \\
\hline Zolmitriptan & 1 RCT [38] & $\begin{array}{l}\text { Early relief: superior to placebo } \\
\text { Adverse events: comparable to placebo }\end{array}$ \\
\hline Almotriptan & 1 RCT [39] & $\begin{array}{l}\text { Superior to placebo in pain-free status at } 2 \text { and } 24 \mathrm{~h} \text {; significant reduction } \\
\text { in nausea and photophobia; adverse events comparable to placebo }\end{array}$ \\
\hline \multicolumn{3}{|l|}{ Combination drugs } \\
\hline Sumatriptan + naproxen & 5 RCTs [50-52] & $\begin{array}{c}\text { Early relief: superior to placebo } \\
\text { Sustained relief: superior to placebo, especially with } \\
\text { comorbid dysmenorrhea } \\
\text { Adverse events: comparable to placebo } \\
\text { Other outcomes: patient satisfaction, productivity, quality of life }\end{array}$ \\
\hline $\begin{array}{l}\text { Frovatriptan }+ \\
\text { dexketoprofen }\end{array}$ & $1 \mathrm{RCT}[53]$ & $\begin{array}{l}\text { Early relief: superior to frovatriptan alone } \\
\text { Sustained relief: superior to frovatriptan alone } \\
\text { Adverse events: comparable to frovatriptan alone }\end{array}$ \\
\hline
\end{tabular}


When considering the management of $\mathrm{MM}$, as well as of migraine in general, the treating physician should consider the woman's comorbidities that might influence the hormonal status. Collaboration between headache physicians and gynecologists is encouraged to manage menstrual irregularities and reproductive conditions that can influence migraine. Notably, some medical comorbidities, such as obesity, have a higher impact on women than on men [54-56]. Adipokines and leptin have been implied in the interaction between obesity and migraine [57], and obesity has a complex relationship with female sex hormones in terms of appetite regulation and adipose tissue distribution [58]. The management of MM should take into account the whole medical condition of women and all the possible internal and external influencing factors.

\section{Prevention of Menstrual Migraine}

The available migraine preventive agents are also effective on MM, as shown by an open-label study on topiramate [59] and by a post hoc analysis of a randomized controlled trial of erenumab [60]. However, migraine tends to have a menstrual-related pattern even under effective prevention, with more frequent episodes in the perimenstrual than in the non-menstrual period, as shown by open-label studies on topiramate and erenumab $[59,61]$. This means that conventional preventatives cannot counterbalance the hormonal trigger. For this reason, specific hormonal strategies may be needed if a woman continues to consistently experience disabling menstrual attacks despite effective ongoing prevention for non-menstrual attacks.

Preventive treatment is started when migraine significantly interferes with the patient's life [62]. In the case of MM, and mostly pure menstrual migraine, the impairment in quality of life can be severe, although only during a few days each month. Hence, common migraine preventatives, which are prescribed for daily use, might not have a net benefit. It is useful to plan MM-specific strategies for prevention, especially in women with pure MM. Such strategies include short-term prevention and hormonal manipulation.

\subsection{Short-Term Prevention with Triptans or NSAIDs}

Short-term prevention of MM is particularly useful in women taking oral contraceptives or with very regular menstrual cycles, in whom the period of maximum susceptibility to migraine is easily predictable. It can also be applied as an integration to standard prophylaxis in women with menstrual-related migraine not adequately controlled by standard prevention. This kind of treatment focuses on decreasing the burden of migraine during the days of highest susceptibility, while avoiding continuous prophylaxis and its potential adverse events. When considering a short-term prophylaxis, it should be kept in mind that natural menstrual cycles are subject to huge variations; according to a study, the perimenstrual period can be accurately predicted only in $27 \%$ of cases [63]. The available trials have assessed the efficacy of common analgesics, including naproxen [64] and nimesulide [65], and several triptans, including frovatriptan [66-68], naratriptan [69,70], and zolmitriptan [71] [Table 2]; all those drugs were taken for 5 to 14 days around the start of menstruation. The trials' results are largely positive, with the highest quality of evidence available for frovatriptan and naratriptan [4]. Higher doses of triptans were generally more effective than lower doses, while maintaining safety (Table 2). However, the daily use of triptans for the short-term prevention of MM has the drawback of possible ineffectiveness in women with irregular duration of menstrual cycles. Besides, the daily use of triptans can expose women to medication overuse [72]. It might be advisable to prescribe triptans as short-term prevention only to women with very regular menstrual cycles or under combined hormonal treatments and pure MM to maximize efficacy while minimizing the risk of medication overuse.

\subsection{Hormonal Prevention}

Hormonal manipulation strategies are an alternative option for the management of MM based on the estrogen withdrawal hypothesis. These strategies aim at preventing MM 
by reducing or suppressing the fall in estrogen levels that precedes menstruation. This goal can be achieved by short-term hormonal supplementation or by the continuous use of exogenous hormones in fixed doses, without hormone-free intervals. It should be kept in mind that the intermittent formulations of oral combined hormonal contraceptives usually exacerbate migraine as they lead to higher fluctuations in estrogen levels compared with natural menstrual cycles [73,74].

As far as short-term estrogen supplementation is concerned, several trials have assessed the efficacy of estrogen gel [75-77] or patches [78,79] to mitigate the estrogen fall during the perimenstrual days (Table 2). Following a similar strategy, a further open-label study suggested the efficacy of an oral contraceptive containing $20 \mu \mathrm{g}$ ethinyl estradiol on days 1 to 21 , supplemented with $0.9 \mathrm{mg}$ conjugated equine estrogens on days 22 to 28 , for the prevention of MM [74]. It is important to note that short-term estrogen supplementation is effective as long as it counteracts estrogen withdrawal; hence, the best use of estrogen supplementation is during the whole estrogen-free interval of oral contraceptives, especially if containing low estrogen doses [74].

Table 2. Summary of drugs for the short-term prophylaxis of menstrual migraine. RCT indicates randomized controlled trial.

\begin{tabular}{|c|c|c|c|}
\hline Drug & Available Studies & Treatment Protocol & Main Findings \\
\hline \multicolumn{4}{|l|}{ NSAIDs } \\
\hline Naproxen & $1 \mathrm{RCT}[64]$ & $\begin{array}{l}500 \mathrm{mg} \text { twice daily for } 14 \text { days } \\
\text { for } 3 \text { cycles }\end{array}$ & $\begin{array}{l}\text { Significant reduction in number, } \\
\text { duration, and severity of attacks } \\
\text { compared with placebo only during } \\
\text { the } 2 \text { nd and 3rd cycle }\end{array}$ \\
\hline Nimesulide & $1 \mathrm{RCT}[65]$ & $\begin{array}{l}100 \mathrm{mg} \text { thrice daily for } 10 \\
\text { days for } 3 \text { cycles }\end{array}$ & $\begin{array}{c}\text { Significant reduction in pain intensity } \\
\text { and duration compared with placebo } \\
\text { during all the cycles }\end{array}$ \\
\hline \multicolumn{4}{|l|}{ Triptans } \\
\hline Frovatriptan & $\begin{array}{l}2 \text { RCTs, } 1 \text { open-label } \\
\text { extension [66-68] }\end{array}$ & $\begin{array}{l}2.5 \mathrm{mg} \text { daily or twice daily for } \\
6 \text { days }\end{array}$ & $\begin{array}{l}\text { Significant reduction in headache } \\
\text { days, headache intensity, headache } \\
\text { duration, and use of rescue } \\
\text { medication; twice daily formulation } \\
\text { better than daily formulation }\end{array}$ \\
\hline Naratriptan & $1 \mathrm{RCT}[70]$ & $\begin{array}{c}1 \mathrm{mg} \text { or } 2.5 \mathrm{mg} \text { twice daily for } \\
5 \text { days for } 3 \text { cycles }\end{array}$ & $\begin{array}{l}\text { Significant reduction in headache } \\
\text { days, headache intensity, headache } \\
\text { duration, and use of rescue } \\
\text { medication; significant improvement } \\
\text { in quality of life; } 2.5 \mathrm{mg} \text { dose better } \\
\text { than } 1 \mathrm{mg} \text { dose }\end{array}$ \\
\hline Zolmitriptan & $1 \mathrm{RCT}[71]$ & $\begin{array}{c}2.5 \mathrm{mg} \text { twice or thrice daily for } \\
7 \text { days for } 3 \text { cycles }\end{array}$ & $\begin{array}{l}\text { Significant reduction in headache } \\
\text { days, pain recurrence, and rescue } \\
\text { medication with both doses }\end{array}$ \\
\hline \multicolumn{4}{|l|}{ Hormone supplementation } \\
\hline Percutaneous estradiol & 3 RCTs [75-77] & $7-10$ days for $2-3$ cycles & $\begin{array}{l}\text { Significant reduction in headache } \\
\text { days and acute medication use, only } \\
\text { during the treatment, with } \\
\text { subsequent rebound headache; good } \\
\text { tolerability profile }\end{array}$ \\
\hline $\begin{array}{c}\text { Transdermal } 17 \\
\beta \text {-estradiol }\end{array}$ & 1 RCTs [78] & 6 days for 3 cycles & $\begin{array}{c}\text { Estradiol effective only if } \\
\text { synchronized with menstruation }\end{array}$ \\
\hline $\begin{array}{l}\text { Conjugated equine } \\
\text { estrogens }\end{array}$ & 1 Open-label [74] & $\begin{array}{l}7 \text { days (hormone-free interval } \\
\text { of a combined contraceptive) } \\
\text { for } 2 \text { cycles }\end{array}$ & $\begin{array}{l}\text { At least } 50 \% \text { reduction in monthly } \\
\text { headache days in all treated women; } \\
\text { improvement in menstrual symptoms }\end{array}$ \\
\hline
\end{tabular}


An alternative strategy to prevent $\mathrm{MM}$ in women seeking contraception is to use specific formulations of low-dose estrogens and/or progestins, such as estradiol valerate plus dienogest [80]. Continuous administration of estrogen, without [81] or with a reduced time hormone-free interval [82], or the use of non-oral formulations, such as the vaginal ring [83], also showed efficacy in decreasing the burden of MM (Figure 4).

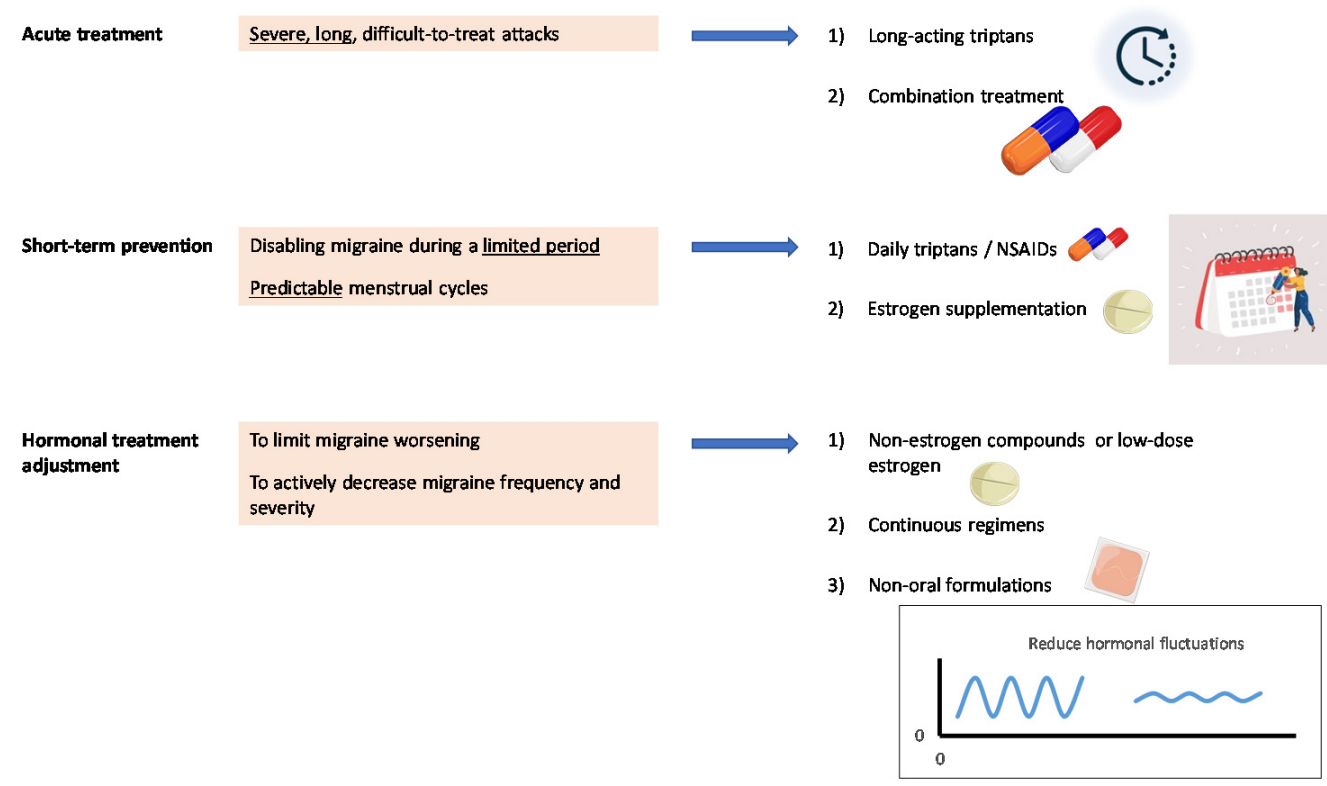

Figure 4. Suggestions for the treatment of menstrual migraine in clinical practice.

An alternative modality of hormonal manipulation is the use of phytoestrogen; the daily use of a combination of soy isoflavones, dong quai, and black cohosh, all of which contain phytoestrogens, effectively decreased headache frequency in women with menstrualrelated migraine without aura in a randomized controlled trial [84]. A further trial suggested the efficacy of the soy isoflavones genisteine and diadzeine in controlling MM [85]. Using phytoestrogens instead of the usual estrogen formulations could also mitigate the vascular risk associated with combined hormonal contraception [86], which is an important concern in women with migraine [87].

Hormonal treatments differentially affect migraine with and without aura, as migraine without aura tends to follow a menstrual-related pattern more frequently than migraine with aura [88,89]. Female sex hormones affect the two forms of migraine in different ways; while estrogen withdrawal is a trigger for migraine without aura, high estrogen states are a trigger for migraine aura [89]. This clinical finding is supported by animal models in which high estrogen states acted as a trigger for cortical spreading depression, the pathophysiological correlate of aura [90]. It is likely that women with migraine with aura undergo migraine exacerbations if exposed to combined hormonal contraceptives and mostly those with high estrogen doses. Besides, women with migraine with aura have a highly increased vascular risk, which could be further increased by using combined hormonal contraceptives [91]. Therefore, the use of exogenous estrogens should be best avoided in women reporting auras.

The induction of pharmacological menopause could theoretically prevent MM by stopping the cycles of continuous rise and fall of estrogen levels that exacerbate migraine; however, evidence suggests that medically induced menopause alone is not adequate for migraine prevention, and that adding exogenous estradiol provides only modest preventive benefit [92]. 


\subsection{Non-Pharmacological Treatments}

Non-pharmacological treatments can be useful in women with MM who refuse or have contraindications to hormonal or other pharmacological treatments; in addition, they can be used as adjunctive short-term treatments. A small trial showed the efficacy of $360 \mathrm{mg}$ daily magnesium in decreasing MM frequency compared with placebo [93]. Another small randomized controlled trial showed the efficacy of 400 daily units of vitamin E over placebo in decreasing pain intensity and headache-related disability [94]. Notably, some nutrients, and mostly magnesium, are also useful for the treatment of premenstrual syndrome [95]. Herbal products have limited but promising evidence in the treatment of MM overlapping with premenstrual symptoms; vitex agnus-castus showed effective control of those symptoms in an open-label study [96]. A randomized controlled trial showed the benefit of transcranial direct current stimulation in MM over placebo [97]; however, this technique is of limited availability. From a practical point of view, we deem it reasonable to prescribe perimenstrual nutrients such as magnesium to women reporting disabling pure $\mathrm{MM}$ associated with premenstrual symptoms.

\section{Considerations on the Treatment of Perimenopausal Migraine}

The menopausal transition is a process occurring over several years characterized by wide fluctuations that ends in stable low levels of both estrogens and progestins [98]. The susceptibility to migraine is highest in the late premenopausal and perimenopausal period, when hormonal fluctuations reach their maximum [9]. The hormonal fluctuations of perimenopause are associated with the occurrence of mood changes, weight gain, and vasomotor symptoms such as hot flashes, which are particularly common in women with migraine [99]. There are no specific guidelines for the preventive treatment of migraine during the menopausal transition; nevertheless, some special considerations may apply to that population of women regarding both hormonal and non-hormonal treatments.

\section{Hormonal Treatments}

Hormonal replacement therapy (HRT). HRT is usually prescribed to reduce the vasomotor symptoms associated with the menopausal transition [100,101]. However, population-based studies suggest that HRT worsens migraine $[32,102,103]$. To limit migraine worsening after the menopause, different strategies are viable based on the estrogen withdrawal hypothesis, including the continuous rather than intermittent administration of combined hormonal treatments [104], the intrauterine or transdermal rather than oral administration of estrogen [105], and the administration of non-estrogen compounds such as tibolone [106]. An alternative strategy could be the use of phytoestrogens such as soy isoflavones, which can control menopausal symptoms [107] together with hormone-related migraine. The types and doses of estrogens and progestins in HRT can also have a different impact on migraine. As high-estrogen states can increase the susceptibility to migraine with aura [89], the use of the lowest possible doses of estrogens can contribute to avoiding the exacerbation of migraine during the menopausal transition. This result is suggested by an early case series of four patients developing migraine aura after starting HRT and in whom reducing the estrogen dose or avoiding the oral route of administration led to the disappearance of aura [108]. Referring to progestins, the use of products without androgenic properties or natural progesterone [109] or non-oral routes of administration [110] might be beneficial to migraine [111].

When considering hormonal treatments for postmenopausal women, the possible benefits should be compared with the risk of cerebrovascular events, which is increased both by migraine itself and by estrogens [91,112,113], even at the lowest doses [87]. Women with migraine, and mostly those with migraine with aura, who enter the perimenopausal period should be advised to avoid HRT if possible due to the potential harms to their health. Antidepressants such as escitalopram or venlafaxine can be used to control both vasomotor symptoms and migraine in postmenopausal women in whom HRT is contraindicated $[114,115]$. 
The efficacy of venlafaxine against perimenopausal vasomotor symptoms was comparable to that of HRT with estrogen according to a randomized clinical trial [116]; venlafaxine is also an effective treatment for migraine [117] and can therefore represent a valid alternative to hormonal treatments in the management of perimenopausal migraine. More limited evidence is available on the migraine-preventing effects of paroxetine [118], escitalopram [119], and gabapentin [120]; however, all those agents can also be used to treat hot flashes [121-123] and can therefore be effectively used for the treatment of migraine in perimenopause. Among non-pharmacologic treatments, vitamin E, acupuncture, and physical exercise have modest evidence of effect on both vasomotor symptoms and migraine [124].

Figure 5 summarizes the suggestions for migraine treatment that may specifically apply to perimenopausal women.

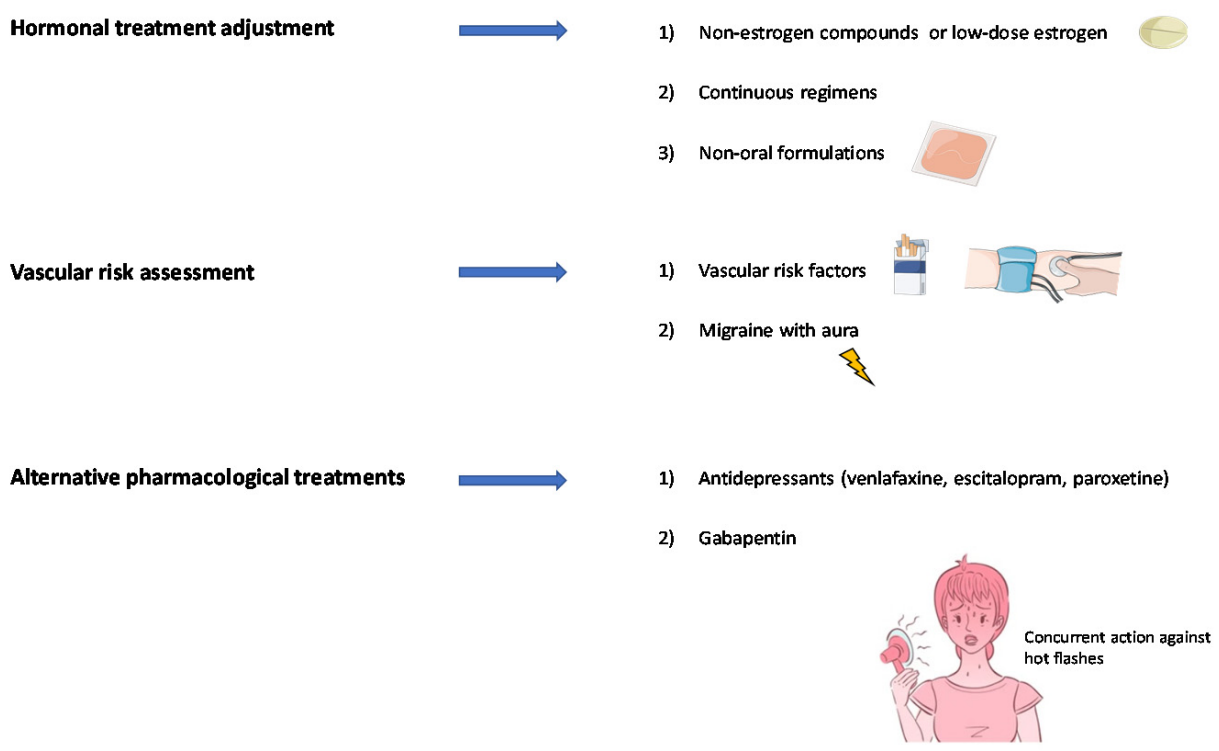

Figure 5. Suggestions for the treatment of perimenopausal migraine in clinical practice.

\section{Conclusions and Future Directions}

The influence of female sex hormone fluctuations on migraine is well known. However, the mechanisms underlying that influence are still unclear, hindering the development of new treatments specific for hormone-related migraine. To date, the most specific treatments for menstrual and perimenopausal migraine are based on hormone manipulation, with the goal of limiting the fluctuations in estrogen levels that exacerbate migraine frequency and severity. Further studies are needed to understand the complex interplay between female sex hormones and the mechanisms of migraine generation. There is evidence that estrogens can modulate several neurotransmitter systems, including the serotonergic, GABAergic, and opioid systems in the brain [4]. High estrogen levels also increase the levels of calcitonin gene-related peptide (CGRP), which is strictly implied in the generation of migraine pain [10]. Given the high prevalence of migraine in women, the design of future migraine treatments should consider the interactions between sex hormones and migraine.

The current approach to migraine treatment includes acute treatments, which are given for each headache episode, and preventive treatments, which are given on a continuative basis for months to years. The so-called "short-term prophylaxis" of MM is in fact the continuous use of treatments designed to be acute, with the consequent risk of medication overuse, especially in women that cannot predict the duration of their menstrual cycles. There is a need for a more versatile approach to the treatment of MM that can overcome the distinction between acute and preventative treatments. Interestingly, gepants, the oral CGRP receptor antagonists, can act both as acute and as preventative migraine treatments [125]. This is particularly true for rimegepant, which has been proven effective in both roles by randomized controlled trials [126-128]. Telcagepant, taken perimenstrually 
for seven days, effectively reduced perimenstrual headache days, although not the absolute number of headache days, over placebo in a randomized controlled trial [129]. The clinical development of telcagepant was stopped because of tolerability issues; nevertheless, it suggests that gepants can be effective over migraine attacks exacerbated by female sex hormone fluctuations. Specific studies are needed for the specific 5-HT-1F receptors, ditans. Lasmiditan has been proven effective in two large randomized controlled trials $[130,131]$ and we cannot exclude its efficacy on MM as it shares some mechanisms of action with triptans. Together with the development of new migraine treatments, combined hormonal treatment strategies should be refined to find the best combinations and ways of administration in women with MM and perimenopausal migraine, in order to achieve better migraine control or avoid migraine worsening.

As shown by the successful application of treatments acting on the CGRP pathway, elucidating the mechanisms of migraine can lead to significant improvements in its management. Uncovering the mechanisms by which female sex hormones influence migraine will likely lead to further improvements in the treatment of hormone-dependent headaches.

Author Contributions: Conceptualization, R.O. and S.S.; writing-original draft preparation, R.O.; writing-review and editing, C.D.F., V.C., E.D.M., F.P., S.S. All authors have read and agreed to the published version of the manuscript.

Funding: This research received no external funding.

Institutional Review Board Statement: Not applicable.

Informed Consent Statement: Not applicable.

Acknowledgments: For Figures 1 and $3-5$ we used the archives of Servier Medical Art (Available online: https: / / smart.servier.com; accessed on 8 March 2021) and Shutterstock (Available online: https:/ / www.shutterstock.com; accessed on 20 March 2021).

Conflicts of Interest: S.S. reports personal fees from Allergan-Abbvie, AstraZeneca, Abbott, Eli Lilly Teva and Novo Nordisk, and grants from Novartis. R.O. reports personal fees from Novartis, Eli Lilly, Teva, and non-financial support from Allergan. No other disclosures were reported.

\section{References}

1. Collaborators, G.H. Global, regional, and national burden of migraine and tension-type headache, 1990-2016: A systematic analysis for the Global Burden of Disease Study 2016. Lancet Neurol. 2018, 17, 954-976.

2. Burch, R.C.; Buse, D.C.; Lipton, R.B. Migraine: Epidemiology, Burden, and Comorbidity. Neurol. Clin. 2019, 37, 631-649. [CrossRef] [PubMed]

3. Steiner, T.J.; Stovner, L.J.; Jensen, R.; Uluduz, D.; Katsarava, Z. Migraine remains second among the world's causes of disability, and first among young women: Findings from GBD2019. J. Headache Pain 2020, 21, 137. [CrossRef] [PubMed]

4. Vetvik, K.G.; MacGregor, E.A. Menstrual migraine: A distinct disorder needing greater recognition. Lancet Neurol. 2021, 20, 304-315. [CrossRef]

5. Victor, T.W.; Hu, X.; Campbell, J.C.; Buse, D.C.; Lipton, R.B. Migraine prevalence by age and sex in the United States: A life-span study. Cephalalgia 2010, 30, 1065-1072. [CrossRef] [PubMed]

6. Delaruelle, Z.; Ivanova, T.A.; Khan, S.; Negro, A.; Ornello, R.; Raffaelli, B.; Terrin, A.; Mitsikostas, D.D.; Reuter, U. Male and female sex hormones in primary headaches. J. Headache Pain. 2018, 19, 117. [CrossRef]

7. MacGregor, E.A.; Frith, A.; Ellis, J.; Aspinall, L.; Hackshaw, A. Incidence of migraine relative to menstrual cycle phases of rising and falling estrogen. Neurology 2006, 67, 2154-2158. [CrossRef]

8. Calhoun, A.H. Understanding Menstrual Migraine. Headache 2018, 58, 626-630. [CrossRef]

9. Sacco, S.; Ripa, P.; Ornello, R.; Degan, D.; Tiseo, C.; Stewart, J.; Pistoia, F.; Carolei, A.; Sacco, S. Migraine in menopausal women: A systematic review. Int. J. Women's Health 2015, 7, 773-782. [CrossRef]

10. Ramírez, A.L.; Rubio-Beltrán, E.; Villalón, C.M.; MaassenVanDenBrink, A. Gender aspects of CGRP in migraine. Cephalalgia 2017, 39, 435-444. [CrossRef]

11. Warfvinge, K.; Krause, D.N.; Maddahi, A.; Edvinsson, J.C.A.; Edvinsson, L.; Haanes, K.A. Estrogen receptors $\alpha, \beta$ and GPER in the CNS and trigeminal system-molecular and functional aspects. J. Headache Pain 2020, 21, 131. [CrossRef]

12. Rossetti, M.F.; Cambiasso, M.J.; Holschbach, M.A.; Cabrera, R. Oestrogens and Progestagens: Synthesis and Action in the Brain. J. Neuroendocr. 2016, 28. [CrossRef] [PubMed]

13. Amandusson, Å.; Blomqvist, A. Estrogenic influences in pain processing. Front. Neuroendocr. 2013, 34, 329-349. [CrossRef] [PubMed] 
14. Tzabazis, A.; Kori, S.; Mechanic, J.; Miller, J.; Pascual, C.; Manering, N.; Carson, D.; Klukinov, M.; Spierings, E.; Jacobs, D.; et al. Oxytocin and Migraine Headache. Headache: J. Head Face Pain 2017, 57 (Suppl. 2), 64-75. [CrossRef] [PubMed]

15. Aggarwal, M.; Puri, V.; Puri, S. Effects of Estrogen on the Serotonergic System and Calcitonin Gene-Related Peptide in Trigeminal Ganglia of Rats. Ann. Neurosci. 2012, 19, 151-157. [CrossRef] [PubMed]

16. Tzabazis, A.; Mechanic, J.; Miller, J.; Klukinov, M.; Pascual, C.; Manering, N.; Carson, D.S.; Jacobs, A.; Qiao, Y.; Cuellar, J.; et al. Oxytocin receptor: Expression in the trigeminal nociceptive system and potential role in the treatment of headache disorders. Cephalalgia 2016, 36, 943-950. [CrossRef] [PubMed]

17. Hornung, R.; Benton, W.L.; Tongkhuya, S.; Uphouse, L.; Kramer, P.R.; Averitt, D.L. Progesterone and Allopregnanolone Rapidly Attenuate Estrogen-Associated Mechanical Allodynia in Rats with Persistent Temporomandibular Joint Inflammation. Front. Integr. Neurosci. 2020, 14, 26. [CrossRef]

18. Olesen, J. Headache Classification Committee of the International Headache Society (IHS) The International Classification of Headache Disorders, 3rd edition. Cephalalgia 2018, 38, 1-211.

19. Couturier, E.G.M.; Bomhof, M.A.M.; Neven, A.K.; Van Duijn, N.P. Menstrual Migraine in A Representative Dutch Population Sample: Prevalence, Disability and Treatment. Cephalalgia 2003, 23, 302-308. [CrossRef]

20. Vetvik, K.G.; MacGregor, E.A.; Lundqvist, C.; Russell, M.B. Prevalence of menstrual migraine: A population-based study. Cephalalgia 2013, 34, 280-288. [CrossRef]

21. Granella, F.; Sances, G.; Allais, G.; Nappi, R.E.; Tirelli, A.; Benedetto, C.; Brundu, B.; Facchinetti, F.; Nappi, G. Characteristics of menstrual and nonmenstrual attacks in women with menstrually related migraine referred to headache centres. Cephalalgia 2004, 24, 707-716. [CrossRef] [PubMed]

22. MacGregor, E.A.; Victor, T.W.; Hu, X.; Xiang, Q.; Puenpatom, R.A.; Chen, W.; Campbell, J.C. Characteristics of Menstrual vs Nonmenstrual Migraine: A Post Hoc, Within-Woman Analysis of the Usual-Care Phase of a Nonrandomized Menstrual Migraine Clinical Trial. Headache J. Head Face Pain 2010, 50, 528-538. [CrossRef]

23. Vetvik, K.G.; Benth, J.Š.; MacGregor, E.A.; Lundqvist, C.; Russell, M.B. Menstrual versus non-menstrual attacks of migraine without aura in women with and without menstrual migraine. Cephalalgia 2015, 35, 1261-1268. [CrossRef] [PubMed]

24. Güven, B.; Güven, H.; Çomoğlu, S. Clinical characteristics of menstrually related and non-menstrual migraine. Acta Neurol. Belg. 2017, 117, 671-676. [CrossRef] [PubMed]

25. Peres, M.F.; Mercante, J.P.; Guendler, V.Z.; Corchs, F.; Bernik, M.A.; Zukerman, E.; Silberstein, S.D. Cephalalgiaphobia: A possible specific phobia of illness. J. Headache Pain 2007, 8, 56-59. [CrossRef]

26. Giannini, G.; Zanigni, S.; Grimaldi, D.; Melotti, R.; Pierangeli, G.; Cortelli, P.; Cevoli, S. Cephalalgiaphobia as a feature of high-frequency migraine: A pilot study. J. Headache Pain 2013, 14, 49. [CrossRef]

27. Martin, V.T.; Pavlovic, J.; Fanning, K.M.; Buse, D.C.; Reed, M.L.; Lipton, R.B. Perimenopause and Menopause Are Associated With High Frequency Headache in Women With Migraine: Results of the American Migraine Prevalence and Prevention Study. Headache J. Head Face Pain 2016, 56, 292-305. [CrossRef]

28. Wang, S.J.; Fuh, J.L.; Lu, S.R.; Juang, K.D.; Wang, P.H. Migraine prevalence during menopausal transition. Headache 2003, 43, 470-478. [CrossRef]

29. Makita, K.; Inagaki, M.; Kitamura, S.; Tatsuoka, Y. Changes in migraine before and after menopause in Japanese climacteric women. Cephalalgia 2017, 37, 1088-1092. [CrossRef]

30. Oh, K.; Jung, K.-Y.; Choi, J.-Y.; Seo, W.-K.; Park, K.-W. Headaches in Middle-Aged Women during Menopausal Transition: A Headache Clinic-Based Study. Eur. Neurol. 2012, 68, 79-83. [CrossRef]

31. MacGregor, E.A. Menstruation, Sex Hormones, and Migraine. Neurol. Clin. 1997, 15, 125-141. [CrossRef]

32. Ornello, R.; Caponnetto, V.; Frattale, I.; Sacco, S. Patterns of Migraine in Postmenopausal Women: A Systematic Review. Neuropsychiatr. Dis. Treat. 2021, 17, 859-871. [CrossRef] [PubMed]

33. Dowson, A.J.; Massiou, H.; Aurora, S.K. Managing migraine headaches experienced by patients who self-report with menstrually related migraine: A prospective, placebo-controlled study with oral sumatriptan. J. Headache Pain 2005, 6, 81-87. [CrossRef]

34. Landy, S.; Savani, N.; Shackelford, S.; Loftus, J.; Jones, M. Efficacy and tolerability of sumatriptan tablets administered during the mild-pain phase of menstrually associated migraine. Int. J. Clin. Pr. 2004, 58, 913-919. [CrossRef]

35. Nett, R.; Landy, S.; Shackelford, S.; Richardson, M.S.; Ames, M.; Lener, M. Pain-Free Efficacy after Treatment with Sumatriptan in the Mild Pain Phase of Menstrually Associated Migraine. Obstet. Gynecol. 2003, 102, 835-842. [PubMed]

36. Newman, L.C.; Harper, S.; Jones, B.A.; Campbell, J. Frovatriptan for Acute Treatment of Migraine Associated with Menstruation: Results from an Open-Label Postmarketing Surveillance Study. J. Women's Health 2009, 18, 1265-1273. [CrossRef]

37. Massiou, H.; Jamin, C.; Hinzelin, G.; The French Naramig Collaborative Study Group; Bidaut-Mazel, C. Efficacy of oral naratriptan in the treatment of menstrually related migraine. Eur. J. Neurol. 2005, 12, 774-781. [CrossRef]

38. Loder, E.; Silberstein, S.D.; Abu-Shakra, S.; Mueller, L.; Smith, T. Efficacy and tolerability of oral zolmitriptan in menstrually associated migraine: A randomized, prospective, parallel-group, double-blind, placebo-controlled study. Headache 2004, 44, 120-130. [CrossRef]

39. Allais, G.; Bussone, G.; D’Andrea, G.; Moschiano, F.; d'Onofrio, F.; Valguarnera, F.; Manzoni, G.C.; Grazzi, L.; Allais, R.; Benedetto, C.; et al. Almotriptan $12.5 \mathrm{mg}$ in menstrually related migraine: A randomized, double-blind, placebo-controlled study. Cephalalgia 2011, 31, 144-151. [CrossRef] 
40. Allais, G.; Tullo, V.; Omboni, S.; Benedetto, C.; Sances, G.; Zava, D.; Ferrari, M.D.; Bussone, G. Efficacy of frovatriptan versus other triptans in the acute treatment of menstrual migraine: Pooled analysis of three double-blind, randomized, crossover, multicenter studies. Neurol. Sci. 2012, 33 (Suppl. 1), S65-S69. [CrossRef]

41. Bartolini, M.; Giamberardino, M.A.; Lisotto, C.; Martelletti, P.; Moscato, D.; Panascia, B.; Savi, L.; Pini, L.A.; Sances, G.; Santoro, P.; et al. Frovatriptan versus almotriptan for acute treatment of menstrual migraine: Analysis of a double-blind, randomized, cross-over, multicenter, Italian, comparative study. J. Headache Pain 2012, 13, 401-406. [CrossRef] [PubMed]

42. Savi, L.; Omboni, S.; Lisotto, C.; Zanchin, G.; Ferrari, M.D.; Zava, D.; Pinessi, L. Efficacy of frovatriptan in the acute treatment of menstrually related migraine: Analysis of a double-blind, randomized, cross-over, multicenter, Italian, comparative study versus rizatriptan. J. Headache Pain 2011, 12, 609-615. [CrossRef] [PubMed]

43. Durham, P.L.; Vause, C.V.; Derosier, F.; McDonald, S.; Cady, R.; Martin, V. Changes in salivary prostaglandin levels during menstrual migraine with associated dysmenorrhea. Headache 2010, 50, 844-851. [CrossRef] [PubMed]

44. Mannix, L.K. Menstrual-Related Pain Conditions: Dysmenorrhea and Migraine. J. Women's Health 2008, 17, 879-891. [CrossRef]

45. Antonova, M.; Wienecke, T.; Olesen, J.; Ashina, M. Prostaglandin E(2) induces immediate migraine-like attack in migraine patients without aura. Cephalalgia 2012, 32, 822-833. [CrossRef]

46. Al-Waili, N.S. Treatment of menstrual migraine with prostaglandin synthesis inhibitor mefenamic acid: Double-blind study with placebo. Eur. J. Med. Res. 2000, 5, 176-182.

47. Vane, J.R.; Botting, R.M. Mechanism of action of nonsteroidal anti-inflammatory drugs. Am. J Med. 1998, 104, 2S-8S, discussion 21S-22S. [CrossRef]

48. Facchinetti, F.; Allais, G.; Nappi, R.E.; Gabellari, I.C.; Di Renzo, G.C.; Genazzani, A.R.; Bellafronte, M.; Roncolato, M.; Benedetto, C. Sumatriptan (50 mg tablets vs. $25 \mathrm{mg}$ suppositories) in the acute treatment of menstrually related migraine and oral contraceptive-induced menstrual migraine: A pilot study. Gynecol. Endocrinol. 2010, 26, 773-779. [CrossRef]

49. Allais, G.; Castagnoli Gabellari, I.; Rolando, S.; Benedetto, C. Evaluation of the use of sumatriptan-naproxen sodium for menstrual migraine and dysmenorrhea. Expert Rev. Neurother. 2011, 11, 1383-1387. [CrossRef]

50. Cady, R.K.; Diamond, M.L.; Diamond, M.P.; Ballard, J.E.; Lener, M.E.; Dorner, D.P.; DeRosier, F.J.; McDonald, S.A.; White, J.; Runken, M.C. Sumatriptan-Naproxen Sodium for Menstrual Migraine and Dysmenorrhea: Satisfaction, Productivity, and Functional Disability Outcomes. Headache 2011, 51, 664-673. [CrossRef]

51. Martin, V.T.; Ballard, J.; Diamond, M.P.; Mannix, L.K.; DeRosier, F.J.; Lener, S.E.; Krishen, A.; McDonald, S.A. Relief of Menstrual Symptoms and Migraine with a Single-Tablet Formulation of Sumatriptan and Naproxen Sodium. J. Women's Health 2014, 23, 389-396. [CrossRef] [PubMed]

52. Mannix, L.K.; Martin, V.T.; Cady, R.K.; Diamond, M.L.; Lener, S.E.; White, J.D.; DeRosier, F.J.; McDonald, S.A. Combination treatment for menstrual migraine and dysmenorrhea using sumatriptan-naproxen: Two randomized controlled trials. Obstet. Gynecol. 2009, 114, 106-113. [CrossRef] [PubMed]

53. Allais, G.; Bussone, G.; Tullo, V.; Cortelli, P.; Valguarnera, F.; Barbanti, P.; Sette, G.; D’Onofrio, F.; Curone, M.; Benedetto, C. Frovatriptan $2.5 \mathrm{mg}$ plus dexketoprofen $(25 \mathrm{mg}$ or $37.5 \mathrm{mg}$ ) in menstrually related migraine. Subanalysis from a double-blind, randomized trial. Cephalalgia 2014, 35, 45-50. [CrossRef] [PubMed]

54. Ornello, R.; Ripa, P.; Pistoia, F.; Degan, D.; Tiseo, C.; Carolei, A.; Sacco, S. Migraine and body mass index categories: A systematic review and meta-analysis of observational studies. J. Headache Pain 2015, 16, 27. [CrossRef] [PubMed]

55. Gelaye, B.; Sacco, S.; Brown, W.J.; Nitchie, H.L.; Ornello, R.; Peterlin, B.L. Body composition status and the risk of migraine: A meta-analysis. Neurology 2017, 88, 1795-1804. [CrossRef] [PubMed]

56. Peterlin, B.L.; Rosso, A.L.; Williams, M.A.; Rosenberg, J.R.; Haythornthwaite, J.A.; Merikangas, K.R.; Gottesman, R.F.; Bond, D.S.; He, J.P.; Zonderman, A.B. Episodic migraine and obesity and the influence of age, race, and sex. Neurology 2013, 81, 1314-1321. [CrossRef]

57. Peterlin, B.L.; Sacco, S.; Bernecker, C.; Scher, A.I. Adipokines and Migraine: A Systematic Review. Headache 2016, 56, 622-644. [CrossRef]

58. Leeners, B.; Geary, N.; Tobler, P.N.; Asarian, L. Ovarian hormones and obesity. Hum. Reprod. Update 2017, 23, 300-321. [CrossRef]

59. Allais, G.; Del Rio, M.S.; Diener, H.-C.; Benedetto, C.; Pfeil, J.; Schäuble, B.; von Oene, J. Perimenstrual migraines and their response to preventive therapy with topiramate. Cephalalgia 2010, 31, 152-160. [CrossRef]

60. Pavlovic, J.M.; Paemeleire, K.; Göbel, H.; Bonner, J.; Rapoport, A.; Kagan, R.; Zhang, F.; Picard, H.; Mikol, D.D.; Rapoport, A. Efficacy and safety of erenumab in women with a history of menstrual migraine. J. Headache Pain 2020, 21, 95. [CrossRef]

61. Ornello, R.; Frattale, I.; Caponnetto, V.; De Matteis, E.; Pistoia, F.; Sacco, S. Menstrual Headache in Women with Chronic Migraine Treated with Erenumab: An Observational Case Series. Brain Sci. 2021, 11, 370. [CrossRef] [PubMed]

62. Schwedt, T.J. Preventive Therapy of Migraine. Contin. Lifelong Learn. Neurol. 2018, 24, 1052-1065. [CrossRef] [PubMed]

63. MacGregor, E.A. Perimenstrual headaches: Unmet needs. Curr. Pain Headache Rep. 2008, 12, 468-474. [CrossRef] [PubMed]

64. Sances, G.; Martignoni, E.; Fioroni, L.; Blandini, F.; Facchinetti, F.; Nappi, G. Naproxen sodium in menstrual migraine prophylaxis: A double-blind placebo controlled study. Headache 1990, 30, 705-709. [CrossRef] [PubMed]

65. Giacovazzo, M.; Gallo, M.F.; Guidi, V.; Rico, R.; Scaricabarozzi, I. Nimesulide in the Treatment of Menstrual Migraine. Drugs 1993, 46 (Suppl. 1), 140-141. [CrossRef]

66. Brandes, J.L.; Poole, A.; Kallela, M.; Schreiber, C.P.; MacGregor, E.A.; Silberstein, S.D.; Tobin, J.; Shaw, R. Short-term frovatriptan for the prevention of difficult-to-treat menstrual migraine attacks. Cephalalgia 2009, 29, 1133-1148. [CrossRef] 
67. MacGregor, E.A.; Brandes, J.L.; Silberstein, S.; Jeka, S.; Czapinski, P.; Shaw, B.; Pawsey, S. Safety and Tolerability of Short-Term Preventive Frovatriptan: A Combined Analysis. Headache J. Head Face Pain 2009, 49, 1298-1314. [CrossRef] [PubMed]

68. Silberstein, S.D.; Elkind, A.H.; Schreiber, C.; Keywood, C. A randomized trial of frovatriptan for the intermittent prevention of menstrual migraine. Neurology 2004, 63, 261-269. [CrossRef]

69. Mannix, L.K.; Savani, N.; Landy, S.; Valade, M.; Shackelford, S.; Ames, M.H.; Jones, M.W. Efficacy and Tolerability of Naratriptan for Short-Term Prevention of Menstrually Related Migraine: Data from Two Randomized, Double-Blind, Placebo-Controlled Studies. Headache J. Head Face Pain 2007, 47, 1037-1049. [CrossRef]

70. Newman, L.; Mannix, L.K.; Landy, S.; Silberstein, S.; Lipton, R.B.; Putnam, D.G.; Watson, C.; Jöbsis, M.; Batenhorst, A.; O'Quinn, S. Naratriptan as short-term prophylaxis of menstrually associated migraine: A randomized, double-blind, placebo-controlled study. Headache 2001, 41, 248-256. [CrossRef]

71. Tuchman, M.M.; Hee, A.; Emeribe, U.; Silberstein, S. Oral zolmitriptan in the short-term prevention of menstrual migraine: A randomized, placebo-controlled study. CNS Drugs 2008, 22, 877-886. [CrossRef]

72. Silberstein, S.; Patel, S. Menstrual migraine: An updated review on hormonal causes, prophylaxis and treatment. Expert Opin. Pharmacother. 2014, 15, 2063-2070. [CrossRef] [PubMed]

73. Sacco, S.; Merki-Feld, G.S.; Ægidius, K.L.; Bitzer, J.; Canonico, M.; Gantenbein, A.R.; Kurth, T.; Lampl, C.; Lidegaard, Ø.; MacGregor, E.A.; et al. Effect of exogenous estrogens and progestogens on the course of migraine during reproductive age: A consensus statement by the European Headache Federation (EHF) and the European Society of Contraception and Reproductive Health (ESCRH). J. Headache Pain 2018, 19, 76. [CrossRef] [PubMed]

74. Calhoun, A.H. A Novel Specific Prophylaxis for Menstrual-associated Migraine. South Med. J. 2004, 97, 819-822. [CrossRef]

75. De Lignières, B.; Vincens, M.; Mauvais-Jarvis, P.; Mas, J.L.; Touboul, P.J.; Bousser, M.G. Prevention of menstrual migraine by percutaneous oestradiol. Br. Med. J. Clin. Res. Ed. 1986, 293, 1540. [CrossRef]

76. Dennerstein, L.; Morse, C.; Burrows, G.; Oats, J.; Brown, J.; Smith, M. Menstrual migraine: A double-blind trial of percutaneous estradiol. Gynecol. Endocrinol. 1988, 2, 113-120. [CrossRef]

77. MacGregor, E.A.; Frith, A.; Ellis, J.; Aspinall, L.; Hackshaw, A. Prevention of menstrual attacks of migraine: A double-blind placebo-controlled crossover study. Neurology 2006, 67, 2159-2163. [CrossRef]

78. Smits, M.G.; Van Der Meer, Y.G.; Pfeil, J.; Rijnierse, J.; Vos, A.; Smite, M. Perimenstrual Migraine: Effect of Estraderm TTS(r) and the Value of Contingent Negative Variation and Exteroceptive Temporalis Muscle Suppression Test. Headache 1994, $34,103-106$. [CrossRef]

79. Almén-Christensson, A.; Hammar, M.; Lindh-Åstrand, L.; Landtblom, A.-M.; Brynhildsen, J. Prevention of menstrual migraine with perimenstrual transdermal 17- $\beta$-estradiol: A randomized, placebo-controlled, double-blind crossover study. Fertil. Steril. 2011, 96, 498-500.e1. [CrossRef]

80. Nappi, R.E.; Terreno, E.; Sances, G.; Martini, E.; Tonani, S.; Santamaria, V.; Tassorelli, C.; Spinillo, A. Effect of a contraceptive pill containing estradiol valerate and dienogest (E2V/DNG) in women with menstrually-related migraine (MRM). Contracept 2013, 88, 369-375. [CrossRef]

81. Göretzlehner, G.; Waldmann-Rex, S.; Schramm, G.A. Extended cycles with the combined oral contraceptive chlormadinone acetate $2 \mathrm{mg}$ / ethinylestradiol $0.03 \mathrm{mg}$ : Pooled analysis of data from three large-scale, non-interventional, observational studies. Clin. Drug Investig. 2011, 31, 269-277. [CrossRef]

82. MacGregor, E.A.; Guillebaud, J. The 7-day contraceptive hormone-free interval should be consigned to history. BMJ Sex. Reprod. Health 2018, 44, 214-220. [CrossRef]

83. Calhoun, A.; Ford, S.; Pruitt, A. The Impact of Extended-Cycle Vaginal Ring Contraception on Migraine Aura: A Retrospective Case Series. Headache 2012, 52, 1246-1253. [CrossRef]

84. Burke, B.E.; Olson, R.D.; Cusack, B.J. Randomized, controlled trial of phytoestrogen in the prophylactic treatment of menstrual migraine. Biomed. Pharmacother. 2002, 56, 283-288. [CrossRef]

85. Ferrante, F.; Fusco, E.; Calabresi, P.; Cupini, L.M. Phyto-oestrogens in the Prophylaxis of Menstrual Migraine. Clin. Neuropharmacol. 2004, 27, 137-140. [CrossRef]

86. Xu, Z.; Li, Y.; Tang, S.; Huang, X.; Chen, T. Current use of oral contraceptives and the risk of first-ever ischemic stroke: A meta-analysis of observational studies. Thromb. Res. 2015, 136, 52-60. [CrossRef]

87. Ornello, R.; Canonico, M.; Merki-Feld, G.S.; Kurth, T.; Lidegaard, Ø.; MacGregor, E.A.; Lampl, C.; Nappi, R.E.; Martelletti, P.; Sacco, S. Migraine, low-dose combined hormonal contraceptives, and ischemic stroke in young women: A systematic review and suggestions for future research. Expert Rev. Neurother. 2020, 2020, 1-5. [CrossRef]

88. Granella, F.; Sances, G.; Pucci, E.; Nappi, R.E.; Ghiotto, N.; Napp, G. Migraine with aura and reproductive life events: A case control study. Cephalalgia 2000, 20, 701-707. [CrossRef]

89. MMacGregor, E.A. Oestrogen and attacks of migraine with and without aura. Lancet Neurol. 2004, 3, 354-361. [CrossRef]

90. Sandweiss, A.J.; Cottier, K.E.; McIntosh, M.I.; Dussor, G.; Davis, T.P.; Vanderah, T.W.; Largent-Milnes, T.M. 17- $\beta$-Estradiol induces spreading depression and pain behavior in alert female rats. Oncotarget 2017, 8, 114109-114122. [CrossRef]

91. Sacco, S.; Merki-Feld, G.S.; Egidius, K.L.; Bitzer, J.; Canonico, M.; Kurth, T.; Lampl, C.; Lidegaard, Ø.; MacGregor, E.A.; MaassenVanDenBrink, A. Hormonal contraceptives and risk of ischemic stroke in women with migraine: A consensus statement from the European Headache Federation (EHF) and the European Society of Contraception and Reproductive Health (ESC). J. Headache Pain 2017, 18, 108. [CrossRef] [PubMed] 
92. Martin, V.; Wernke, S.; Mandell, K.; Zoma, W.; Bean, J.; Pinney, S.; Liu, J.; Ramadan, N.; Rebar, R. Medical oophorectomy with and without estrogen add-back therapy in the prevention of migraine headache. Headache: J. Head Face Pain 2003, 43, 309-321. [CrossRef] [PubMed]

93. Facchinetti, F.; Sances, G.; Borella, P.; Genazzani, A.R.; Nappi, G. Magnesium prophylaxis of menstrual migraine: Effects on intracellular magnesium. Headache 1991, 31, 298-301. [CrossRef] [PubMed]

94. Ziaei, S.; Kazemnejad, A.; Sedighi, A. The effect of vitamin E on the treatment of menstrual migraine. Med. Sci. Monit. 2009, 15, CR16-9. [PubMed]

95. Allais, G.; Gabellari, I.C.; Burzio, C.; Rolando, S.; De Lorenzo, C.; Mana, O.; Benedetto, C. Premenstrual syndrome and migraine. Neurol. Sci. 2012, 33 (Suppl. 1), 111-115. [CrossRef]

96. Ambrosini, A.; Di Lorenzo, C.; Coppola, G.; Pierelli, F. Use of Vitex agnus-castus in migrainous women with premenstrual syndrome: An open-label clinical observation. Acta Neurol. Belg. 2012, 113, 25-29. [CrossRef]

97. Wickmann, F.; Stephani, C.; Czesnik, D.; Klinker, F.; Timäus, C.; Chaieb, L.; Paulus, W.; Antal, A. Prophylactic treatment in menstrual migraine: A proof-of-concept study. J. Neurol. Sci. 2015, 354, 103-109. [CrossRef]

98. Harlow, S.D.; Gass, M.; Hall, J.E.; Lobo, R.; Maki, P.; Rebar, R.W.; Sherman, S.; Sluss, P.M.; de Villiers, T.J.; STRAW + 10 Collaborative Group. Executive summary of the Stages of Reproductive Aging Workshop + 10: Addressing the unfinished agenda of staging reproductive aging. Menopause 2012, 19, 387-395. [CrossRef]

99. Carturan, P.; Scorcine, C.; Fragoso, Y.D. Migraine in the post-menopausal period is associated with higher levels of mood disorders, disability, and more menopausal symptoms. Arq. Neuropsiquiatr. 2016, 74, 999-1002. [CrossRef]

100. Stuenkel, C.A.; Davis, S.R.; Gompel, A.; Lumsden, M.A.; Murad, M.H.; Pinkerton, J.V.; Santen, R.J. Treatment of Symptoms of the Menopause: An Endocrine Society Clinical Practice Guideline. J. Clin. Endocrinol. Metab. 2015, 100, 3975-4011. [CrossRef]

101. Hamoda, H.; Panay, N.; Pedder, H.; Arya, R.; Savvas, M. The British Menopause Society \& Women's Health Concern 2020 recommendations on hormone replacement therapy in menopausal women. Post Reprod. Health 2020, 26, 181-209. [PubMed]

102. Misakian, A.L.; Langer, R.D.; Bensenor, I.M.; Cook, N.R.; Manson, J.E.; Buring, J.E.; Rexrode, K.M. Postmenopausal hormone therapy and migraine headache. J. Women's Health 2003, 12, 1027-1036. [CrossRef] [PubMed]

103. Aegidius, K.L.; Zwart, J.A.; Hagen, K.; Schei, B.; Stovner, L.J. Hormone replacement therapy and headache prevalence in postmenopausal women. The Head-HUNT study. Eur. J. Neurol. 2007, 14, 73-78. [CrossRef] [PubMed]

104. Facchinetti, F.; Nappi, R.E.; Tirelli, A.; Polatti, F.; Nappi, G. Hormone Supplementation Differently Affects Migraine in Postmenopausal Women. Headache J. Head Face Pain 2002, 42, 924-929. [CrossRef] [PubMed]

105. Nappi, R.E.; Cagnacci, A.; Granella, F.; Piccinini, F.; Polatti, F.; Facchinetti, F. Course of primary headaches during hormone replacement therapy. Maturitas 2001, 38, 157-163. [CrossRef]

106. Nappi, R.E.; Sances, G.; Sommacal, A.; Detaddei, S.; Facchinetti, F.; Cristina, S.; Polatti, F.; Nappi, G. Different effects of tibolone and low-dose EPT in the management of postmenopausal women with primary headaches. Menopause 2006, 13, 818-825. [CrossRef] [PubMed]

107. Chen, M.-N.; Lin, C.-C.; Liu, C.-F. Efficacy of phytoestrogens for menopausal symptoms: A meta-analysis and systematic review. Climacteric 2015, 18, 260-269. [CrossRef]

108. MacGregor, A. Estrogen replacement and migraine aura. Headache J. Head Face Pain 1999, 39, 674-678. [CrossRef]

109. Silberstein, S.D.; Merriam, G.R. Estrogens, progestins, and headache. Neurology 1991, 41, 786-793. [CrossRef]

110. Panay, N.; Studd, J. Progestogen intolerance and compliance with hormone replacement therapy in menopausal women. Hum. Reprod. Update 1997, 3, 159-171. [CrossRef]

111. Nappi, R.; Sances, G.; Detaddei, S.; Ornati, A.; Chiovato, L.; Polatti, F. Hormonal management of migraine at menopause. Menopause Int. 2009, 15, 82-86. [CrossRef] [PubMed]

112. Sacco, S.; Cerone, D.; Carolei, A. Comorbid neuropathologies in migraine: An update on cerebrovascular and cardiovascular aspects. J. Headache Pain 2008, 9, 237-248. [CrossRef] [PubMed]

113. Sacco, S.; Ricci, S.; Degan, D.; Carolei, A. Migraine in women: The role of hormones and their impact on vascular diseases. J. Headache Pain 2012, 13, 177-189. [CrossRef]

114. North American Menopause Society. Nonhormonal management of menopause-associated vasomotor symptoms: 2015 position statement of The North American Menopause Society. Menopause 2015, 22, 1155-1172. [CrossRef] [PubMed]

115. MacGregor, E.A. Migraine, menopause and hormone replacement therapy. Post Reprod. Health 2017, 24, 11-18. [CrossRef] [PubMed]

116. Joffe, H.; Guthrie, K.A.; LaCroix, A.Z.; Reed, S.D.; Ensrud, K.E.; Manson, J.E.; Newton, K.M.; Freeman, E.W.; Anderson, G.L.; Larson, J.C.; et al. Low-dose estradiol and the serotonin-norepinephrine reuptake inhibitor venlafaxine for vasomotor symptoms: A randomized clinical trial. JAMA Intern. Med. 2014, 174, 1058-1066. [CrossRef]

117. Ozyalcin, S.N.; Talu, G.K.; Kiziltan, E.; Yucel, B.; Ertas, M.; Disci, R. The efficacy and safety of venlafaxine in the prophylaxis of migraine. Headache 2005, 45, 144-152. [CrossRef]

118. Park, H.J.; Lee, S.T.; Shim, J.Y.; Kim, B.; Hwang, S.H.; Kim, S.H.; Park, J.E.; Park, J.H.; Jung, S.H.; Ahn, J.Y.; et al. The Effect of Paroxetine on the Reduction of Migraine Frequency is Independent of Its Anxiolytic Effect. J. Clin. Neurol. 2006, 2, $246-251$. [CrossRef]

119. Tarlaci, S. Escitalopram and Venlafaxine for the Prophylaxis of Migraine Headache Without Mood Disorders. Clin. Neuropharmacol. 2009, 32, 254-258. [CrossRef] 
120. Linde, M.; Mulleners, W.M.; Chronicle, E.P.; McCrory, D.C. Gabapentin or pregabalin for the prophylaxis of episodic migraine in adults. Cochrane Database Syst. Rev. 2013, 2013, CD010609. [CrossRef] [PubMed]

121. Freeman, E.W.; Guthrie, K.A.; Caan, B.; Sternfeld, B.; Cohen, L.S.; Joffe, H.; Carpenter, J.S.; Anderson, G.L.; Larson, J.C.; Ensrud, K.E.; et al. Efficacy of escitalopram for hot flashes in healthy menopausal women: A randomized controlled trial. JAMA 2011, 305, 267-274. [CrossRef] [PubMed]

122. Butt, D.A.; Lock, M.; Lewis, J.E.; Ross, S.; Moineddin, R. Gabapentin for the treatment of menopausal hot flashes: A randomized controlled trial. Menopause 2008, 15, 310-318. [CrossRef] [PubMed]

123. Orleans, R.J.; Li, L.; Kim, M.-J.; Guo, J.; Sobhan, M.; Soule, L.; Joffe, H.V. FDA Approval of Paroxetine for Menopausal Hot Flushes. N. Engl. J. Med. 2014, 370, 1777-1779. [CrossRef]

124. Lauritsen, C.G.; Chua, A.L.; Nahas, S.J. Current Treatment Options: Headache Related to Menopause-Diagnosis and Management. Curr. Treat. Options Neurol. 2018, 20, 7. [CrossRef] [PubMed]

125. De Matteis, E.; Guglielmetti, M.; Ornello, R.; Spuntarelli, V.; Martelletti, P.; Sacco, S. Targeting CGRP for migraine treatment: Mechanisms, antibodies, small molecules, perspectives. Expert Rev. Neurother. 2020, 2, 1-15. [CrossRef]

126. Croop, R.; Goadsby, P.J.; Stock, D.; Conway, C.M.; Forshaw, M.; Stock, E.G.; Coric, V.; Lipton, R.B. Efficacy, safety, and tolerability of rimegepant orally disintegrating tablet for the acute treatment of migraine: A randomised, phase 3, double-blind, placebocontrolled trial. Lancet 2019, 394, 737-745. [CrossRef]

127. Croop, R.; Lipton, R.B.; Kudrow, D.; Stock, D.A.; Kamen, L.; Conway, C.M.; Stock, E.G.; Coric, V.; Goadsby, P.J. Oral rimegepant for preventive treatment of migraine: A phase 2/3, randomised, double-blind, placebo-controlled trial. Lancet 2021, 397, 51-60. [CrossRef]

128. Lipton, R.B.; Croop, R.; Stock, E.G.; Stock, D.A.; Morris, B.A.; Frost, M.; Dubowchik, G.M.; Conway, C.M.; Coric, V.; Goadsby, P.J. Rimegepant, an Oral Calcitonin Gene-Related Peptide Receptor Antagonist, for Migraine. N. Engl. J. Med. 2019, 381, 142-149. [CrossRef]

129. Ho, T.W.; Ho, A.P.; Ge, Y.J.; Assaid, C.; Gottwald, R.; MacGregor, E.A.; Mannix, L.K.; van Oosterhout, W.P.J.; Koppenhaver, J.; Lines, C.; et al. Randomized controlled trial of the CGRP receptor antagonist telcagepant for prevention of headache in women with perimenstrual migraine. Cephalalgia 2016, 36, 148-161. [CrossRef]

130. Goadsby, P.J.; Wietecha, L.A.; Dennehy, E.B.; Kuca, B.; Case, M.G.; Aurora, S.K.; Gaul, C. Phase 3 randomized, placebo-controlled, double-blind study of lasmiditan for acute treatment of migraine. Brain 2019, 142, 1894-1904. [CrossRef]

131. Kuca, B.; Silberstein, S.D.; Wietecha, L.; Berg, P.H.; Dozier, G.; Lipton, R.B.; COL MIG-301 Study Group. Lasmiditan is an effective acute treatment for migraine: A phase 3 randomized study. Neurology 2018, 91, e2222-e2232. [CrossRef] [PubMed] 